\title{
MEKANISME TRANSMISI KEBIJAKAN MONETER DALAM PEREKONOMIAN INDONESIA
}

\author{
Tresia Tiodora Sinaga ${ }^{1}$ \\ I Wayan Sudirman ${ }^{2}$ \\ ${ }^{1,2}$ Fakultas Ekonomi Universitas Udayana (Unud), Bali, Indonesia \\ Email : tresia_tdsinaga@yahoo.com
}

\begin{abstract}
ABSTRAK
Tesis ini menginvestigasi peran dari empat saluran utama dalam transmisi kebijakan moneter di Indonesia. Respon indikator utama makro ekonomi Indonesia terhadap kejutan yang berasal dari Internasional dan domestik diestimasi dengan menggunakan pendekatan model Structural Vector Autoregression (SVAR) ekonomi kecil terbuka dengan menggunakan data bulanan. Asumsi pemblokiran variabel eksogen serta resktriksi nol pada non-recursive matriks kontemporer interaksi antar varaibel digunakan untuk melakukan identifikasi model SVAR Hasil estimasi memperlihatkan bahwa Mekanisme Transmisi Kebijakan Moneter melalui saluran tradisional suku bunga, saluran kredit bank, saluran nilai tukar dan saluran harga aset tidak terbukti efektif dalam mentransmisikan kebijakan moneter ke pasar keuangan maupun pasar barang. Lebih lanjut, dilakukan estimasi dampak kejutan internasional dan domestik terhadap variabel domestik dengan menggunakan tehnik fungsi impuls respon dan variance decomposition. Sebagian besar hasil estimasi respon variabel indikator ekonomi sesuai dengan yang teori ekonomi, namun respon tingkat harga dan nilai tukar tidak seperti yang diharapkan dengan adanya price puzzle dan exchange rate puzzle. Hasil analisa makro ekonomi menemukan kejutan internasional lebih signifikan mempengaruhi fluktuasi variabel domestik dibandingkan kejutan domestik.
\end{abstract}

Kata Kunci : Kebijakan Moneter, Mekanisme Transmisi Kebijakan Moneter, model SVAR

\begin{abstract}
This Thesis investigates the role of monetary transmission mechanism in Indonesia. The responses on leading indicator Indonesia economy to structural shock of Internasional dan domestic are estimated using monthly data of the open economy Structural Vector Autoreggression (SVAR) model approach. Block exogenous assumption on SVAR model and non-recursive zero restriction on $\mathrm{AB}$ model of contemporaneous matrix interaction of variables are imposing for SVAR model identification purpose. The estimation result reveal that Monetary Transmission Mechanism channels : interest rate, credit, exchange rate and assets price did not prove to be strongly effective play a crucial role in changes in financial market and good market. Further, we estimate crucial role of internasional shock and domestic shock using impulse response function and variance decomposition technique. This empirical investigation demonstrates result which more in line with the economic theory. However, result from the impulse response analysis show that price level rises and depreciation, not as expected. This thesis finds that Internasional shock have more a significant impact than domestic shock on Indonesia economy.
\end{abstract}

Keywords : Monetary's policy, Monetary Transmission Mechanism, SVAR 


\section{PENDAHULUAN}

Sejak diterapkannya ITF, dinamika ekonomi domestik yang disertai dengan tingginya ketidakpastian ekonomi dunia mempengaruhi pencapaian target inflasi untuk periode 2005-2016 yang masih jauh dari harapan,seperti yang diperlihatkan gambar 1. hanya enam periode target inflasi yang tercapai dari keseluruhan dua belas periode penelitian. Dalam penerapan kerangka kerja ITF, pemahaman yang baik mengenai Mekanisme Transmisi Kebijakan moneter (MTKM) sangat dibutuhkan dan sama pentingnya dengan pengetahuan mengenai proses inflasi. Mekanisme Transmisi Kebijakan Moneter (MTKM) dapat didefinisikan sebagai suatu proses bagaimana kebijakan moneter bank sentral ditransmisikan kedalam perubahan PDB riil dan infasi (Taylor, 1995)

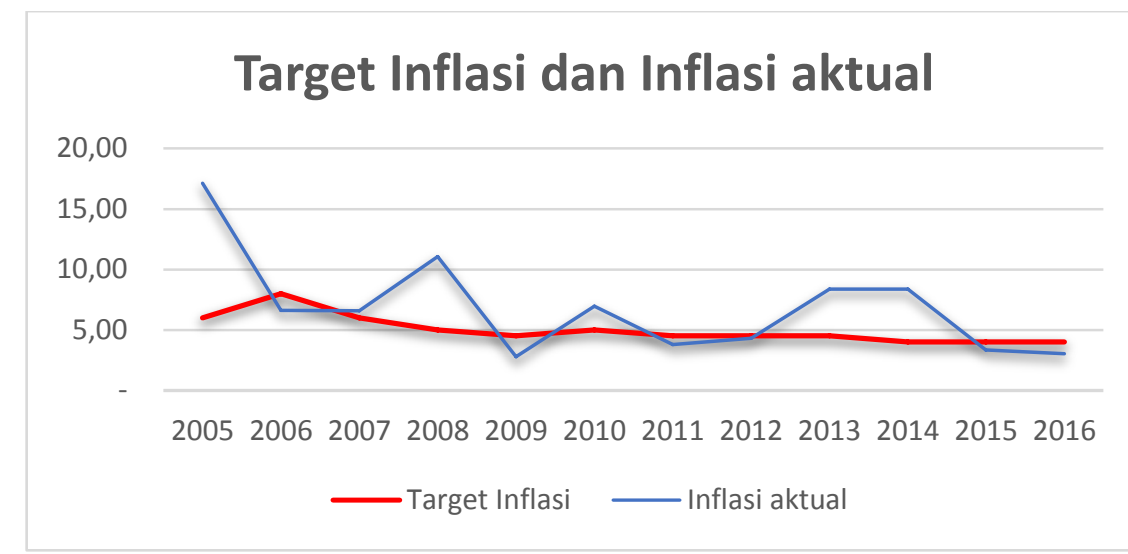

Gambar 1

Sumber : BI

Target inflasi dan inflasi aktual

Suku bunga acuan BI rate dipandang tidak cukup efektif mengimbangi kontraksi kebijakan moneter. Hal ini dapat dilihat dari ketidakmampuan BI rate dalam mengendalikan inflasi, target inflasi yang tidak tercapai bahkan cenderung gagal dalam mengantisipasi tingkat inflasi yang rendah. Kurang lancarnya 
transmisi suku bunga BI ke sektor perbankan dapat menjadi salah satu penyebab kurang efektifnya kinerja BI rate, penurunan suku bunga BI rate sejatinya diikuti dengan penurunan suku bunga deposito yang kemudian mempengaruhi suku bunga pinjaman. Penurunan BI rate tidak mampu mempengaruhi suku bunga pinjaman rata-rata yang masih bertengger di kisaran 12 persen, meningkatnya kredit modal kerja yang terjadi di tiap tahun dalam periode penelitian tidak dipengaruhi oleh suku bunga tetapi kuantitas ketersediaan kredit. Ketika otoritas moneter menurunkan suku bunga acuan tahun 2009, jumlah kredit perbankan naik sebesar 14 persen dari tahun sebelumnya dari 13,914,545 milliar rupiah menjadi 16,153,905 miliar rupiah.

Demikian juga halnya ketika suku bunga acuan mengalami kenaikan pada tahun 2013, volume kredit perbankan masih meningkat sebesar 18 persen dari tahun 2012, dari total kredit 29,598,470 miliar rupiah meningkat menjadi 36,151,434 miliar rupiah di tahun 2013. Hal ini selaras dengan proposisi yang diajukan oleh Kamin (1998), pada negara emerging economy kuantitas atau ketersediaan kredit lebih berpengaruh dari harga kredit itu sendiri, tahun 2016 peningkatan kredit modal kerja dipengaruhi oleh masuknya dana besar-besaran sebagai dampak dari kebijakan fiskal pemerintah melalui program tax amnesty. Turunnya suku bunga acuan BI pada tahun yang sama tidak diselaras dengan suku bunga pinjaman bank.

Dari transmisi Internasional, Indonesia rentan terhadap gejolak global baik itu dari jalur perdagangan maupun dari jalur finansial (modal). Krisis global tahun 2008 memicu terjadinya arus modal keluar dari Indonesia, mengakibatkan neraca 
Modal dan Finansial tahun 2008 difisit sebesar 1,7 milliar dollar AS, yang sebelumnya mengalami surplus sebesar 3,6 miliar dollar AS di Tahun 2007. Volatilitas nilai tukar menekan rupiah sehingga depresiasi rupiah berdampak buruk dengan defisit neraca pembayaran sebesar 1,9 miliar dolar AS. Tekanan nilai tukar juga berimbas pada jalur perdagangan melalui tekanan inflasi yang tinggi (direct pass-through).

Sangat penting untuk memahami secara tepat natur dan durasi impact kebijakan moneter terhadap pasar uang dan sektor riil, berdasarkan pemahaman hubungan antara variabel ini dan variabel-variabel utam makro lainnya (PDB, inflasi, nilai tukar dan lainnya). Salah satu pendekatan statistik yang sering digunakan oleh akademisi dan peneliti adalah model Vector Autoreggression (VAR). Sebagai contoh, sims (1980), Bernanke dan Blinder (1992), Christiano dkk (1996) dan lainnya yang menggunakan model VAR untuk menganalisa kebijakan moneter di Amerika Serikat. Sistem VAR memungkinkan untuk menjawab permasalahan tersebut dengan pemahaman yang lebih baik mengenai hubungan antar variabel-variabel dalam makro ekonomi. Dilain sisi, semakin banyak peneliti yang menjalankan model Structural VAR (SVAR) untuk menguji hubungan antara kebijakan moneter dan variabel utama makro ekonomi, demikian juga dengan penelitian ini. Penelitian ini akan mengukur model Structural vector atoreggression (SVAR) untuk meneliti kebijakan moneter di Indonesia. Terdapat beberapa penelitian sebelumnya menggunakan SVAR untuk mengatasi pitfalls yang terdapat pada model VAR. Gottschalk (2001) memperkenalkan metodologi SVAR untuk mengatasi dampak yang tak terduga dari kejutan. Analisis model 
data berkala multivariat (multivariate date series), model SVAR jauh lebih baik dari model VAR dalam mengevaluasi kejutan struktural (Bhattacharyya dan Sensarma, 2007).

Untuk menganalisa mekanisme transmisi kebijakan moneter di Indonesia, peneliti akan membangun tiga model SVAR untuk ekonomi Indonesia; model SVAR dasar pertama (SVAR IDN) yang digunakan untuk menganalisa kejutan kebijakan moneter domestik dan kejutan Internasional dalam ekonomi Indonesia. Kemudian, model SVAR kedua (IDN EXT1) merupakan model SVAR dasar yang diperluas dengan memasukkan variabel yang berhubungan dengan perdagangan, guna menganalisa dampak kontraksi kebijakan moneter dalam transmisi internasional yang mempengaruhi aktivitas ekspor dan impor. Dan yang terakhir model SVAR (IDN EXT2) yang memasukkan variabel perilaku pengeluaran, guna menganalisa dampak kontraksi kebijakan moneter terhadap konsumsi dan investasi. Penelitian ini akan menggunakan data beruntun (time series data) dari January 2005 sampai Desember 2016. Data diperoleh dari Datastream, International Financial Statistic (IFS), Badan Pusat Statistik (BPS) dan Bank Indonesia

\section{Tujuan Penelitian}

Dari permasalahan yang ditemukan dalam ekonomi Indonesia seperti penjelasan pada bab sebelumnya, maka penelitian ini bertujuan untuk : 1) menganalisa dampak kejutan kontraksi kebijakan moneter yang mempengaruhi output, inflasi dan indikator ekonomi lainnya. Sehingga dapat diidentifikasi faktor utama fluktuasi pada variabel-variabel indikator ekonomi dalam penelitian. 2) 
menganalisa kekuatan relatif masing-masing saluran dari keempat saluran. Oleh karena perbankan masih mendominasi pasar keuangan Indonesia, maka akan diketahui apakah saluran kredit menjadi saluran yang paling besar peran dan pengaruhnya dalam mentransmisikan kebijakan moneter ke sektor riil. 3) menganalisa hubungan keterkaitan antara tingkat keterbukaan ekonomi Indonesia terhadap kejutan eksternal. 4) menganalisa pengaruh kejutan kontraksi moneter terhadap komponen PDB melalui induksi moneter terhadap konsumsi pribadi dan investasi pribadi.

\section{METODE PENELITIAN}

Metodologi model Vector Autoreggressive (VAR) digumakan pertama kali oleh Sims pada tahun 1980. Model VAR essensinya sebuah model regresi ordinal yang mengakomodasi kerangka multivariate yang menjelaskan perubahan sebuah variabel terkait dengan perubahan lag sendiri dan perubahan variabelvariabel yang lain berserta masing-masing lag-nya. Model VAR memperlakukan semua variabel sebagai endogen namun tidak menjalankan restriksi dalam menguji hubungan antar variabel. Order masing-masing variabel dalam VAR disebut Cholesky ordering. Cholesky ordering sangat ditekankan dalam menjalankan analisa VAR karena setiap inovasi yang terdapat dalam model dihitung berdasarkan dekomposisi choleski (Cholesky Decomposition). Hal ini menekankan bahwa model VAR bersifat apriori, melakukan estimasi data tanpa didasari teori yang ada. 
Perbedaan mendasar antara model VAR dengan Structural VAR (SVAR) terletak pada penekanan restriksi. Dalam menjalankan model SVAR, restriksi masing-masing variabel yang dimasukkan dalam model menjadi suatu keharusan. Dengan kata lain, SVAR merupakan sebuah alternative terhadap dekomposis cholesky yang ada pada model VAR. Artinya, fase kristis model SVAR terletak pada identifikasi elemen-elemen dalam matriks. Model VAR (persaman 1.1) dan SVAR (persamaan 1.2) dinotasikan sebagai berikut :

$$
\begin{aligned}
& \mathrm{Y}_{t}=\mathrm{A}_{1} \mathrm{y}_{t}+\mathrm{A}_{2} \mathrm{y}_{t-1}+\ldots+\mathrm{A}_{p} \mathrm{y}_{p-2}+\mathrm{D}+\mathrm{v}_{t} \\
& \mathrm{~A}_{0} \mathrm{y}_{l}=\mathrm{c}_{0}+\mathrm{A}_{1} \mathrm{y}_{t-1}+\mathrm{A}_{2} \mathrm{y}_{t-2}+\ldots+\mathrm{A}_{p} \mathrm{y}_{p-2}+\mathrm{D}+\mathrm{v}_{t}
\end{aligned}
$$

Dimana :

$\mathrm{y}_{t}$ adalah ( $\left.\mathrm{n} \times 1\right)$ representasi vektor variabel endogen

$\mathrm{c}_{0}$ adalah ( $\left.\mathrm{n} \times 1\right)$ representasi dari vektor konstanta

$\mathrm{A}_{i}$ adalah $(\mathrm{n} \times \mathrm{n})$ matriks $(\mathrm{i}=0, \ldots, \mathrm{p})$ dari parameter struktural,

$\mathrm{D}$ merupakan ( $\mathrm{n}$ x 1) vektor variabel eksogen dan

$\mathrm{v}_{t}$ adalah (n x 1) inovasi struktural, diasumsikan ortogonal dan tidak berkolerasi.

\section{Model SVAR ekonomi Indonesia}

Mengikuti Afandi (2005) model dasar SVAR ekonomi Indonesia akan menggunakan 10 variabel utama dan juga mengacu pada Cushman dan Zha (1997) serta Dungey dan Pagan (2000), mengasumsikan sektor eksternal bersifat block-exogenous terhdap ekonomi domestik. Artinya, ekonomi external (sebagai contoh, Amerika Serikat) tidak dipengaruhi oleh fluktuasi dalam ekonomi Indonesia baik itu yang bersifat kontemporer maupun dengan lag. Maka model dasar SVAR ekonomi Indonesia direpresentasikan oleh vektor $\mathrm{X}_{\mathrm{t}}$

$$
\mathrm{X}_{t}=\left(\mathrm{OPW}_{t}, \mathrm{FFR}_{t}, \mathrm{PDB}_{t}, \mathrm{CPI}_{t}, \mathrm{CrBank}_{t}, \mathrm{RCrB}_{t}, \mathrm{M}_{t}, \mathrm{R}_{t}, \mathrm{JSX}_{\mathrm{t}}, \mathrm{E}_{t}\right)^{\mathrm{T}}
$$

Dimana: $\mathrm{OPW}_{t}$ adalah harga minyak dunia dalam mata uang AS dolar, $\mathrm{FFR}_{t}$ merupakan suku bunga bank sentral Amerika Serikat, mewakili proxy suku bunga 
luar negeri, $\mathrm{PDB}_{t}$ adalah $\mathrm{PDB}$ riil, $\mathrm{CPI}_{t}$ adalah Indeks harga konsumen, CrBank merupakan kredit modal kerja, kemudian $\mathrm{RCrB}_{t}$ suku bunga pinjaman dalam rupiah, $\mathbf{M}_{t}$ adalah agregat moneter, sedangkan $\mathrm{R}_{t}$ adalah instrumen kebijakan moneter, $\mathrm{JSX}_{\mathrm{t}}$ harga asset yang direpresentasikan IHSG dan $\mathrm{E}_{t}$ merupakan nilai tukar.

Identifikasi struktural terletak pada hubungan kontemporer antara variabel-variabel endogen pada matriks $\mathrm{A}_{0}$ dimana tidak terdapat retriksi dalam hubungan dengan lag (tabel 1).

Tabel 1

Matriks Kontemporer $\mathbf{A}_{0}$

\begin{tabular}{ccccccccccc}
\hline & WOP & FFR & Y & CPI & CrBank & RCrB & M & R & JSX & E \\
\hline WOP & 1 & & & & & & & & & \\
FFR & $a_{2,1}$ & 1 & & & & & & & & \\
Y & $a_{3,1}$ & & 1 & & & & & & & \\
CPI & & & $a_{4,3}$ & 1 & & & & & & $a_{4,10}$ \\
CrBank & & & $a_{5,3}$ & & 1 & $a_{5,6}$ & & & & \\
RCrB & & & & & & 1 & $a_{6,7}$ & & & \\
M & & & $a_{7,3}$ & $a_{7,4}$ & & $a_{7,6}$ & 1 & & & \\
R & & $a_{8,2}$ & & & & & $a_{8,7}$ & 1 & & $a_{8,10}$ \\
JSX & & $a_{9,2}$ & & $a_{9,4}$ & & $a_{9,6}$ & & $a_{9,8}$ & 1 & $a_{9,10}$ \\
E & $a_{10,1}$ & $a_{10,2}$ & $a_{10,3}$ & $a_{10,4}$ & $a_{10,5}$ & $a_{10,6}$ & $a_{10,7}$ & $a_{10,8}$ & $a_{10,9}$ & 1 \\
\hline
\end{tabular}

\section{Data}

\section{Tabel 2}

Sumber Data

\begin{tabular}{|c|c|c|}
\hline Variabel & Keterangan & Sumber data \\
\hline OPW & Harga minyak dunia & IFS-IMF \\
\hline FFR & $\begin{array}{l}\text { Suku bunga federal Amerika } \\
\text { Serikat }\end{array}$ & IFS-IMF \\
\hline $\mathrm{Y}$ & Produk domestik bruto riil & BPS \\
\hline CPI & Indeks harga konsumen riil & BPS \\
\hline CrBank & Kredit modal kerja nyata & BI \\
\hline $\mathrm{RCrB}$ & $\begin{array}{l}\text { Suku bunga kredit bank, kredit } \\
\text { agregat domestik }\end{array}$ & IFS-IMF \\
\hline M & Moneter agregat, pasokan uang & BI \\
\hline $\mathrm{R}$ & Suku bunga PAUB & IFS-IMF \\
\hline $\mathrm{E}$ & Nilai tukar rupiah/1USD & BI \\
\hline EKS-IMP & Ekspor dan Impor Indonesia & BI \\
\hline
\end{tabular}


Data bulanan time series januari 2005 - desember 2016 digunakan dalam penelitian ini. Data suku bunga (FFR, Rcrbank, dan R) dalam persentase dan data lainya semuanya dalam logaritma natural. Detail data direpresentasikan tabel 2 diatas.

\section{Tahapan Analisa Data}

\section{Estimasi Model VAR(SVAR)}

\section{Uji Akar Unit dan Stasioneritas}

Tabel 3

Uji Akar Unit dan Stasioneritas

\begin{tabular}{|c|c|c|c|c|c|c|c|c|c|c|c|c|c|c|c|}
\hline \multirow[b]{2}{*}{ Series } & \multicolumn{6}{|c|}{ ADF } & \multicolumn{4}{|c|}{ KPSS } & \multicolumn{5}{|c|}{ PP } \\
\hline & $\mathrm{T} / \mathrm{I}$ & $t_{\sigma}$ & $\begin{array}{l}\mathrm{S} / \\
\mathrm{N}\end{array}$ & Diff & $\begin{array}{c}\text { Critica } \\
\text { I } \\
\text { value } \\
\text { level }\end{array}$ & $\begin{array}{c}\mathrm{T} / \\
\mathrm{I}\end{array}$ & $t_{\sigma}$ & $\begin{array}{l}\mathrm{S} / \\
\mathrm{N}\end{array}$ & Diff & $\begin{array}{c}\text { Critica } \\
\text { I } \\
\text { value } \\
\text { level }\end{array}$ & $\begin{array}{l}\mathrm{T} / \\
\mathrm{I}\end{array}$ & $t_{\sigma}$ & $\begin{array}{l}\mathrm{S} / \\
\mathrm{N}\end{array}$ & Diff & $\begin{array}{c}\text { Critica } \\
\text { I } \\
\text { value } \\
\text { level }\end{array}$ \\
\hline WOP & I & $-5,817$ & $S$ & -1 & $1 \%$ & $\begin{array}{c}\mathrm{T} / \\
\mathrm{I}\end{array}$ & $\begin{array}{c}- \\
0,86 \\
9\end{array}$ & $S$ & 0 & $1 \%$ & I & $-8,96$ & $S$ & -1 & $1 \%$ \\
\hline FFR & I & $-1,947$ & $S$ & 0 & $5 \%$ & I & $\begin{array}{c}- \\
0,86 \\
9\end{array}$ & $S$ & 0 & $1 \%$ & I & $-10,87$ & $S$ & -1 & $1 \%$ \\
\hline PDB & I & $\begin{array}{c}- \\
10,96 \\
7\end{array}$ & $S$ & -1 & $1 \%$ & I & $\begin{array}{c}1,38 \\
6\end{array}$ & $S$ & 0 & $1 \%$ & I & $-8,485$ & $\mathrm{~S}$ & -1 & $1 \%$ \\
\hline Pcon & I & $\begin{array}{c}- \\
10,02 \\
8\end{array}$ & $S$ & -1 & $1 \%$ & I & $\begin{array}{c}0,47 \\
3\end{array}$ & $S$ & 0 & $5 \%$ & I & $-9,985$ & $\mathrm{~S}$ & -1 & $1 \%$ \\
\hline Pinv & I & $-9,783$ & $S$ & 0 & $1 \%$ & I & $\begin{array}{c}0,67 \\
5\end{array}$ & $S$ & 0 & $5 \%$ & I & $-9,697$ & $S$ & -1 & $1 \%$ \\
\hline JSX & I & $-9,085$ & $S$ & -1 & $1 \%$ & I & 1,28 & $\mathrm{~S}$ & 0 & $1 \%$ & I & $-9,129$ & $S$ & -1 & $1 \%$ \\
\hline CPI & I & $-3,084$ & $S$ & 0 & $5 \%$ & I & $\begin{array}{c}1,39 \\
5\end{array}$ & $S$ & 0 & $1 \%$ & I & $-3,334$ & $S$ & 0 & $5 \%$ \\
\hline M2 & I & $-4,004$ & $S$ & -1 & $1 \%$ & I & $\begin{array}{c}1,41 \\
4\end{array}$ & $S$ & 0 & $1 \%$ & I & $\begin{array}{c}- \\
13,71 \\
9\end{array}$ & $S$ & -1 & $1 \%$ \\
\hline CrBank & I & $-3,458$ & $S$ & -1 & $5 \%$ & I & $\begin{array}{c}- \\
1,40\end{array}$ & S & 0 & $1 \%$ & I & 12,25 & $S$ & -1 & $1 \%$ \\
\hline $\begin{array}{l}\text { RCrBan } \\
\mathrm{k}\end{array}$ & $\mathrm{T} / \mathrm{I}$ & $-4,29$ & $S$ & 0 & $1 \%$ & I & $\begin{array}{c}0,91 \\
3\end{array}$ & $S$ & 0 & $1 \%$ & I & $-5,765$ & $S$ & -1 & $1 \%$ \\
\hline $\mathrm{R}$ & I & $-3,88$ & $S$ & -1 & $1 \%$ & I & $\begin{array}{c}0,39 \\
8\end{array}$ & $S$ & 0 & $10 \%$ & I & $-4,727$ & $\mathrm{~S}$ & -1 & $1 \%$ \\
\hline$E$ & I & $-4,773$ & $S$ & -1 & $1 \%$ & I & $\begin{array}{c}0,84 \\
7\end{array}$ & $S$ & 0 & $1 \%$ & I & $\begin{array}{c}- \\
10,17 \\
8\end{array}$ & $S$ & -1 & $1 \%$ \\
\hline Ekspor & I & $-6,291$ & $S$ & -1 & $1 \%$ & I & 0,9 & $\mathrm{~S}$ & 0 & $1 \%$ & I & $\begin{array}{c}- \\
17,10 \\
9\end{array}$ & $S$ & -1 & $1 \%$ \\
\hline Import & I & $\begin{array}{c}- \\
18,27 \\
7\end{array}$ & $S$ & -1 & $1 \%$ & I & 1,03 & $S$ & 0 & $1 \%$ & I & $\begin{array}{c}- \\
17,26 \\
5\end{array}$ & $\mathrm{~S}$ & -1 & $1 \%$ \\
\hline
\end{tabular}

Uji Akar unit menjalankan tiga test yang berbeda, yaitu ADF (Augmented Dickey-Fuller), KPSS (Kwiatkowski-Phillips-Schmidt-Shin) dan PP (Phillips and 
Perron). Dengan menjalankan uji ADF, terdapat empat variabel (FFR, Pinv, CPI, RcrBank) yang stasioner pada tingkat level I(0) dengan signifikansi critical value 5 persen, 1 persen, 5 persen dan 1 persen secara berurutan dan variabel lainnya stasioner pada differensial pertama I(1). Uji KPSS menunjukkan hanya terdapat satu variabel (Others_PDB) yang tidak stasioner dan variabel lainnya stasioner pada tingkat level $\mathrm{I}(0)$. Sedikit berbeda dengan hasil uji ADF, pada uji PP ditemukan hanya satu variabel saja yang stasioner pada tingkat level I(0) dan signifikan pada critical value 5 persen serta lainnya stasioner pada I(1) dengan signifikansi 1 persen. Salah satu tujuan dari penggunaan model VAR adalah dalam model ini dapat dijalankan tanpa terkendala permasalahan stasioneritas. Hal ini didukung dengan tujuan utama dari analisis VAR adalah untuk menentukan saling keterhubungan antara variabel bukan untuk menentukan parameter estimasi. Hasil estimasi uji akar unit direpresentasikan tabel 3 di atas.

\section{Uji Structural Break}

Structural breaks merupakan titik-titik waktu dalam pola time series yang berubah (Bai dan Perron, 2003). Hal ini dikarenakan adanya gangguan gunjangangunjangan eksternal atau perubahan tiba-tiba dalam dinamika intrinsik dan menjadi tantangan tersendiri dalam analisa data dan interpretasi. Kesalahan dalam identifikasi structural break dapat membagi periode time series menjadi beberapa subinterval kecil yang berdampak pada signifikansi, terbentuknya parameter baru yang tidak perlu, dan overfitting yang berakibat pada bias-nya hasil estimasi. Fenomena ini disikapi berbeda oleh Rob J Hyndman (2010) yang berargumen Perubahan besar tiba-tiba yang terjadi pada time series, yang sebagian analis 
mengkategorikan sebagai structural break, tanpa mempertimbangkan opsi lain dengan membangun model yang memungkinkan terjadinya perubahan-perubahan yang intens termasuk perubahan besar yang terjadi sesekali. Oleh karena itu, time varying parameter model dianggap lebih realistis dalam mengakomodasi perubahan-perubahan dalam data time series dibanding dengan mengelompokkan data tersebut dengan atau tanpa structural break. Dari hasil uji Chow breakpoint test yang dijalankan untuk mengidentifikasi structural break tahun 2008 sebagai dampak dari krisis global, dan uji Quandt-Andrews untuk mengidentifikasi adanya structural break pada periode yang belum diketahui. Dari hasil kedua uji structural break tersebut tidak ditemukan adanya structural break. Oleh karena itu tahap selanjutnya dijalankan tanpa menggunakan structural break (dummy).

\section{Penentuan panjang Lag, Stabilitas dan Otokolerasi}

Penentuan panjang lag merupakan isu penting dalam menjalankan model VAR, hal ini disebabkan penentuan panjang lag yang salah berimplikasi besar terhadap pilihan-pilihan pada tahapan selanjutnya. Penentuan lag yang terlalu pendek, mengakibatkan munculnya varian sistematik pada residual yang berdampak adanya otokolerasi, dilain pihak pemilihan lag yang terlalu panjang akan mengakibatkan penurunan drastis pada derajat kebebasan (degree of freedom) artinya kekuatan model berkurang.

\section{Tabel 4}

Uji panjang lag Endogenous Variables : WOP FFR PDB CPI JSX M2 CRBANK RcrBank R EKSPOR IMPOR

\begin{tabular}{ccccccc}
\hline Lag & LogL & LR & FPE & AIC & SC & HQ \\
\hline $\mathbf{0}$ & 1101,264 & NA & $2,53 \mathrm{e} 22$ & $-15,6728$ & $-15,4195$ & $-15,5569$ \\
$\mathbf{1}$ & 3203,259 & 3810,811 & $1,48 \mathrm{e}-34$ & $-43,8454$ & $-40,552^{*}$ & $-42,507^{*}$ \\
$\mathbf{2}$ & 3423,103 & 360,6068 & $5,19-\mathrm{e} 35$ & $-44,9367$ & -38.6033 & $-42,3630$ \\
$\mathbf{3}$ & 3596,214 & 254,0623 & $3,81 \mathrm{e} 35^{*}$ & $-45,3556$ & $-35,9821$ & $-41,5464$
\end{tabular}




\begin{tabular}{ccccccc}
$\mathbf{4}$ & 3733,986 & 178,4104 & $5,20 \mathrm{e}-35$ & $-45,2659$ & $-32,8525$ & $-40,2214$ \\
$\mathbf{5}$ & 3904,856 & $191,7675^{*}$ & $5,21 \mathrm{e}-35$ & $-45,652^{*}$ & $-30,1991$ & $-39,3727$ \\
\hline
\end{tabular}

Tabel 4 memberikan hasil estimasi seleksi panjang lag optimal. SC (Schwarz information criterion) dan HQ (Hannan-Quinn information criterion) merekomendasikan 2 lag, FPE (Final prediction error) merekomendasikan 1 lag sedangkan LR (Sequential modified LR test statistic at 5\%) dan AIC (Akaike information criterion) merekomendasikan 5 lag.

Karena pilihan terbaik antara 2 lag atau 5 lag, mengacu pada Liew dan Terrence (2005) serta Ivanov dan Kilian (2005) yang merekomendasikan AIC sebagai criteia terkuat untuk data observasi bulanan, maka kemudian dipilih lag 5 .

Namun sebelum melakukan analisa, terlebih dahulu memastikan lag yang dipilih bebas dari otokolerasi dan stabil. Uji otokolerasi pada lag 5 kemudian dijalankan, hasil estimasi diperlihatkan tabel 1.4 tersebut dibawah ini, dimana nilai LM p-value 3,67 persen, sehingga hipotesis nol uji otokolerasi LM test tidak dapat ditolak. Artinya, tidak terdapat otokolerasi pada lag 5 (tabel 5).

\section{Tabel 5}

\begin{tabular}{|ccc|}
\multicolumn{3}{|c|}{ Uji Kolerasi VAR LM test } \\
\hline Lags & LM-Statistic & Probability \\
\hline 1 & 189,4548 & 0,0066 \\
2 & 154,5041 & 0,2599 \\
3 & 225,3354 & 0,0000 \\
4 & 182,3234 & 0,0169 \\
$\mathbf{5}$ & $\underline{\mathbf{1 4 9 , 1 5 2 7}}$ & $\underline{\mathbf{0 , 3 6 7 2}}$ \\
$\mathbf{6}$ & 170,2286 & 0,0669 \\
7 & 147,1546 & 0,4115 \\
8 & 124,7036 & 0,8754 \\
9 & 126,0685 & 0,8564 \\
10 & 148,8838 & 0,3731 \\
11 & 140,6191 & 0,5641 \\
\hline
\end{tabular}




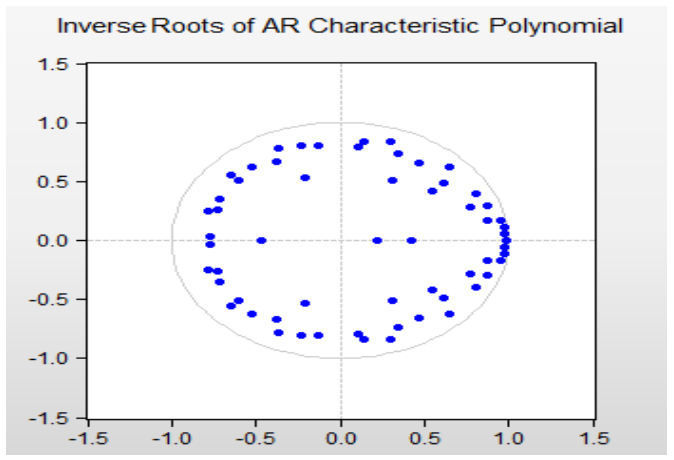

Gambar 2

Uji Stabilital residual VAR

Stabilitas model merupakan hal krusial dalam model VAR. Gambar 2 dibawah ini menunjukkan hasil uji stabilitas model, seluruh nilai modulus kurang dari satu, tidak terdapat variabel-variabel yang eksplosif sehingga dipastikan model stabil.

\section{Uji Normalitas.}

Dari hasil olah normalitas sebagian besar variabel dan joint component menolak hipotesis nol dengan tingkat signifikan yang tinggi, hal ini berarti model VAR tersebut belum lepas dari permasalahan normalitas.

\section{PEMBAHASAN ANALISA IMPULSE RESPONSE dan VARIANCE DECOMPOSITION}

\section{Impulse response dan Variance Decomposition Domestik Indonesia}

Analisa impuls respon merupakan salah satu metode untuk memahami bagaimana kebijakan atau kejutan mempengaruhi variabel-variabel endogen dalam proses VAR yang diteliti. Setelah model SVAR teridentifikasi, impuls respon akan menggambarkan respon-respons terhadap kejutan struktural yang memiliki intepretasi ekonomi. Dengan kata lain, setelah model SVAR melalui 
tahap identifikasi dan estimasi, pengaruh kejutan structural $u_{t}$, dapat diinvestigasi dengan menggunakan analisa impuls respon.

\subsection{Impuls Respon Variabel Domestik terhadap Kejutan Eksternal}

Seperti diilustrasikan gambar 3, Kejutan satu standar deviasi suku bunga FFR direspon positif dan signifikan suku bunga domestik (R), juga respon positif nilai tukar dengan apresiasi rupiah sesuai dengan yang diharapkan, kemudian disusul dengan penurunan tingkat harga yang diilustrasikan dengan respon negatif inflasi (CPI) dan kemudian respon negatif produktivitas dengan penurunan output (PDB) yang direspon setelah 10 bulan delay sebagai dampak dari lag. Secara umum respon terhadap kejutan eksternal yang berasal dari perubahan suku bunga FFR sesuai dengan teori ekonomi.

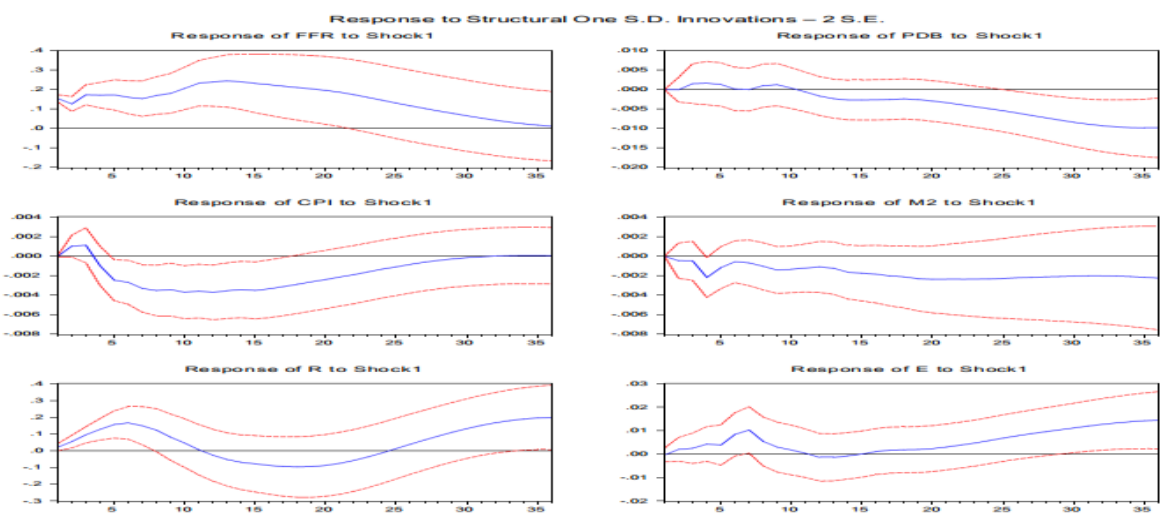

Gambar 3

Impuls respons kejutan FFR

Inovasi positif suku bunga FFR direspon spontan oleh Bank Indonesia dengan menaikkan suku bunga $\mathrm{R}$, dampak kejutan ini masih signifikan sampai pada bulan ke delapan. Bagi investor yang mencari yield yang lebih baik maka selisih dari kenaikan suku bunga Indonesia menjadi peluang, dengan yield 7\%, Indonesia menjadi tujuan investasi potensial, diantara negara asia lainnya yang 
menawarkan yield yang lebih rendah (malaysia $(3,92$ persen), Filipina $(4,97)$ persen, singapura (2,20 persen) dan vietnam (7,01 persen). Derasnya arus modal masuk melalui investasi portofolio terlihat dari tren kenaikan IHSG dan juga berhasil mendongkrak apresiasi nilai tukar rupiah. Apresiasi rupiah mendorong meningkatnya volume impor yang direspon dengan penurunan tingkat harga setelah lag. Respon output terlihat setelah delay 10 bulan selaras dengan hilangnya pengaruh apresiasi rupiah. Pergerakan tidak signifikan Fluktuasi output sebelum merespon negatif dengan penurunan output di bulan 10 mengindikasikan derasnyanya arus modal masuk tidak berdampak signifikan terhadap sektor riil.

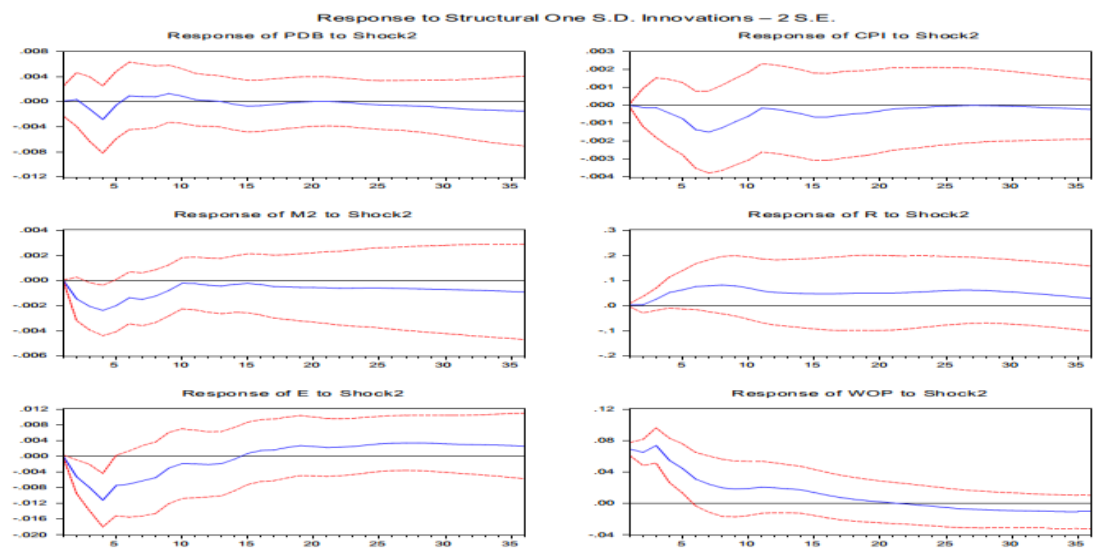

Gambar 4

Impuls respon kejutan WOP

Gambar 4 di atas memperlihatkan respon variabel domestik terhadap kejutan harga minyak dunia. Output (PDB) dan harga (CPI) tidak bergerak signifikan dalam merespon kejutan WOP, meskipun Indonesia sebagai negara net importir minyak, perubahan harga minyak dunia WOP tidak berpengaruh signifikan terhadap output dan harga. Hal ini disebabkan harga minyak domestik ditetapkan oleh pemerintah dan menyesuaikan harga melalui program subsidi. Respon positif nilai tukar (E) terhadap shock WOP signifikan di empat bulan 
pertama dan setelah kuartal pertama memperkuat respon PDB dan CPI. Inovasi positif harga minyak dunia menekan stabilitas rupiah, sehingga rupiah terdepresiasi, signifikan pada kuartal pertama sebelum mulai terapresiasi dibulan ke lima. Hal ini kemungkinan disebabkan oleh peningkatan aktivitas perdagangan Indonesia.

\subsection{Impuls Respon Variabel Domestik terhadap Kejutan Suku Bunga Domestik (R)}

Kebijakan moneter ketat dengan menaikkan suku bunga acuan yang diikuti dengan apresiasi mata uang dalam negeri, maka diharapkan akan mendorong turunnya harga, output dan permintaan uang.
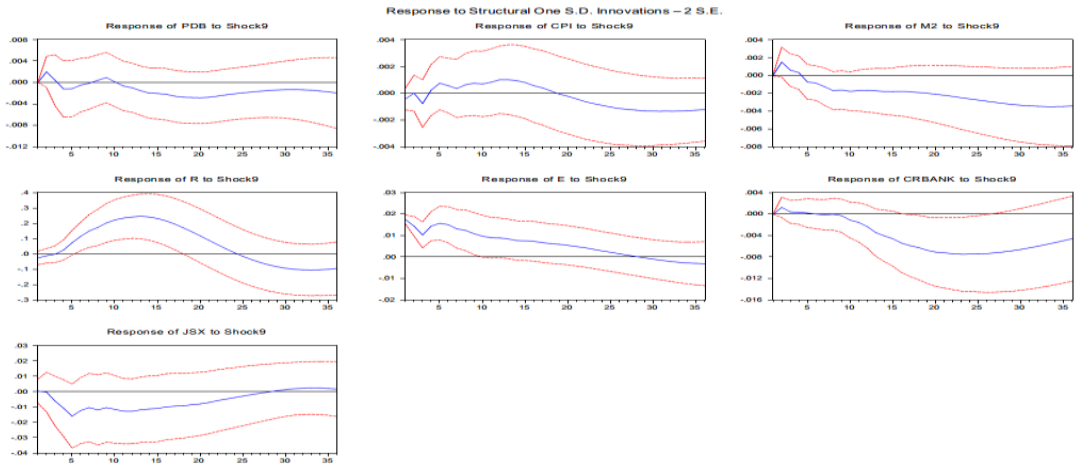

Gambar 5

Impuls respon kejutan suku bunga $(R)$

Gambar 5 menyajikan estimasi impuls respons variabel kunci ekonomi terhadap kejutan suku bunga domestik (R). Keseluruhan variabel-variabel kunci ekonomi Indonesia yang ada dalam model merespon sesuai dengan yang diharapkan, terkecuali variabel harga (CPI) dan nilai tukar (E) tidak seperti yang diharapkan. Kejutan inovasi positif $\mathrm{R}$ direspon dengan kenaikan harga dan depresiasi rupiah, hal ini mengindikasikan adanya price puzzle dan exchange rate puzzle. Depresiasi rupiah disaat suku bunga naik diakibatkan adanya 
ketidakseimbangan pada sektor perdagangan, rendahnya aktivitas ekspor tidak dapat menyeimbangkan tekanan besarnya aktivitas impor, untuk memenuhi kebutuhan pasokan bahan baku produsen yang sebahagian besar menggunakan bahan baku mentah dan bahan baku setengah jadi impor. Kebijakan intervensi rupiah dijalankan untuk mengantisipasi tekanan inflasi sebagai dampak dari tingginya biaya produksi (supply price shock). Hal ini digambarkan dengan respon depresiasi rupiah vice versa respon harga terhadap kejutan suku bunga (R). Defisit perdagangan juga mengakibatkan defisit pada neraca pembayaran. Kebijakan intervensi rupiah dalam mengantisipasi cost-push inflation berdampak pada perlambatan pertumbuhan ekonomi yang ditandai dengan penurunan output. Respon output terhadap kejutan suku bunga domestik menggambarkan hal ini. Harga aset merespon positif terhadap kejutan R setelah 5 bulan lag.

\subsection{Impuls Respon Variabel Domestik terhadap Kejutan Credit Bank (CrBank)}

Respon variabel kunci ekonomi Indonesia terhadap kejutan kredit diilustrasikan gambar 6. Inovasi positif kejutan kredit bank (CrBank) merepresentasikan kebijakan moneter ekspansif. Harga merespon positif terhadap kejutan kredit, demikian juga uang beredar dan harga aset merespon sesuai dengan yang diharapkan. Kejutan positif kredit bank yang direspon positif CPI dapat diintrepretasikan dengan kenaikan jumlah kredit bank menciptakan permintaan serta harga. Kenaikan suku bunga (R) merespon inovasi positif kejutan kredit, merupakan intrepetasi peran kebijakan moneter dalam melakukan stabilisasi dalam ekonomi. 



\section{Gambar 6 \\ Impuls respon kejutan kredit (CrBank)}

Dampak kejutan kredit yang direspon kenaikan output dan apresiasi nilai tukar sepenuhnya merupakan response offset kedua variabel tersebut terhadap kebijakan moneter (Leon Berkelmans, 2005). Dampak kejutan CrBank hanya berpengaruh terhadap variabel-variabel ekonomi dalam rentang waktu yang singkat. Dampak kejutan CrBank terhadap output tidak berpengaruh besar, ditandai dengan fluktuasi respon yang rendah. Hal ini dijelaskan dengan peran intermediasi bank yang belum maksimal dalam menyalurkan kredit terutama kredit peruntukan konsumsi. Sikap kehati-hatian bank dalam menyalurkan kredit, dengan sulitnya akses konsumen mendapatkan pinjaman bukan hanya memperlambat aktivitas ekonomi, excess likuiditas bank juga tidak sehat karena memperlambat laju pertumbuhan ekonomi.

\subsection{Impuls Respon Variabel Domestik terhadap Kejutan Nilai Tukar (E)}

Hasil estimasi impuls respon variabel domestik terhadap kejutan nilai tukar (E) direpresentasikan gambar 7. Kejutan satu standar deviasi nilai tukar merepresentasikan apresiasi mata uang domestik. Inivasi positif nilai tukar 
signifikan mempengaruhi harga aset pada triwulan pertama, ditandai dengan tren kenaikan harga asset (JSX). Apresiasi rupiah juga menstimulus impor dan menurunkan tingkat daya saing perdagangan internasional yang berdampak negatif pada perputaran ekspor. Hal ini menginduksi penurunan output secara siginifikan yang diperlihatkan respon negatif pada awal periode kejutan E, fenomena yang sering ditemui pada ekonomi kecil dan terbuka seperti Indonesia. Apreasiasi nilai tukar juga direspon positif suku bunga domestik (R), yang diikuti dengan penurunan moneter agregat (M2) dan harga (CPI).
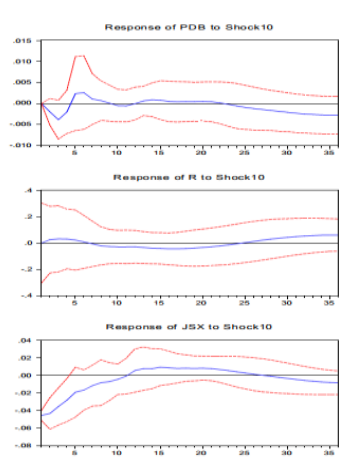

\section{Gambar 7}

Impuls Respon kejutan nilai tukar (E)

\subsection{Variance Decomposition SVAR Ekonomi Indonesia}

Forward Error Variance Decomposition (FEVD) merepresentasikan proporsi pergerakan dalam satu variabel yang disebabkan error oleh kejutan yang berasal dari variabel itu sendiri atau digerakkan oleh variabel yang lainnya dalam model. Variance Decomposition SVAR IDN pada tabel 6 di atas. Fluktuasi PDB dominan berasal dari diri sendiri, meliputi 60 persen dari keseluruhan. Transmisi kebijakan dipengaruhi oleh nilai tukar (E) dan bunga kredit (RcrBank) namun tidak signifikan. Tidak berbeda jauh dengan PDB, hampir 80 persen di awal periode fluktuasi variabel harga (CPI) dijelaskan oleh fluktuasi diri sendiri, 
kemudian fluktuasi dijelaskan oleh FFR sebesar 40 persen seiring dengan penurunan fluktuasi CPI. Nilai tukar lebih besar menjelaskan fluktuasi CPI dibanding saluran lainnya. Suku bunga (R) menjelaskan fluktuasi dirinya sendiri, kemudian FFR. Secara spontan harga asset menjelaskan fluktuasi suku bunga (R) tapi hanya berlangsung singkat. Dalam pasar keuangan (direpresentasikan oleh CrBank- saluran kredit, nilai tukar dan JSX - saluran harga aset), pengaruh pasar uang (direpresentasikan $\mathrm{R}$ - suku bunga dan M2 - pasokan uang) pada variabel E lebih besar pengaruhnya daripada pada variabel CrBank dan JSX. Khususnya, mayoritas fluktuasi E dijelaskan oleh inovasi R lebih dari 50 persen pada jangka pendek. Di awal periode dalam jangka pendek, hampir keseluruhan variasi CrBank dijelaskan oleh dirinya sendiri.

Tabel 6 Variance Decomposition SVAR IDN 1

\begin{tabular}{|c|c|c|c|c|c|c|c|c|c|c|c|}
\hline & Month & FFR & WOP & PDB & CPI & $\mathrm{R}$ & M & CrBank & RcrB & JSX & E \\
\hline \multirow{7}{*}{$\overrightarrow{\widetilde{Z}}$} & 1 & 0,00 & 0,01 & 99,99 & 0,00 & 0,00 & 0,00 & 0,00 & 0,00 & 0,00 & 0,00 \\
\hline & 6 & 0,69 & 1,08 & 80,98 & 1,38 & 2,02 & 5,57 & 2,11 & 1,93 & 0,72 & 3,52 \\
\hline & 12 & 1,00 & 1,16 & 73,54 & 2,40 & 1,95 & 8,75 & 2,19 & 5,33 & 0,75 & 2,92 \\
\hline & 18 & 3,40 & 1,06 & 64,45 & 3,34 & 2,24 & 8,81 & 1,91 & 9,60 & 2,57 & 2,62 \\
\hline & 24 & 7,96 & 0,94 & 57,56 & 2,99 & 2,96 & 8,33 & 1,71 & 10,58 & 4,59 & 2,37 \\
\hline & 30 & 20,50 & 0,91 & 47,04 & 2,49 & 3,17 & 6,84 & 1,57 & 10,35 & 4,49 & 2,63 \\
\hline & 36 & 34,73 & 1,06 & 35,30 & 1,91 & 2,57 & 5,27 & 1,60 & 10,28 & 3,88 & 3,39 \\
\hline \multirow{7}{*}{$\mathcal{\theta}$} & 1 & 0,00 & 0,00 & 1,44 & 97,72 & 0,00 & 0,00 & 0,00 & 0,12 & 0,72 & 0,00 \\
\hline & 6 & 9,92 & 1,57 & 0,58 & 49,13 & 0,96 & 22,54 & 10,20 & 0,51 & 1,03 & 3,56 \\
\hline & 12 & 29,85 & 2,50 & 0,67 & 27,92 & 1,26 & 14,11 & 8,87 & 6,23 & 1,61 & 6,98 \\
\hline & 18 & 37,54 & 2,24 & 0,61 & 20,59 & 1,27 & 10,66 & 6,51 & 10,98 & 1,90 & 7,69 \\
\hline & 24 & 38,54 & 2,06 & 0,70 & 18,31 & 1,14 & 9,61 & 5,81 & 14,12 & 2,12 & 7,59 \\
\hline & 30 & 36,86 & 1,95 & 1,19 & 17,28 & 1,07 & 9,17 & 5,64 & 15,78 & 3,79 & 7,27 \\
\hline & 36 & 35,02 & 1,88 & 2,32 & 16,45 & 1,04 & 9,06 & 5,60 & 16,16 & 5,54 & 6,92 \\
\hline \multirow{7}{*}{$\mathrm{R}$} & 1 & 2,24 & 0,03 & 1,15 & 0,50 & 74,78 & 17,91 & 0,00 & 0,28 & 3,11 & 0,00 \\
\hline & 6 & 27,45 & 4,42 & 1,75 & 2,51 & 20,24 & 24,87 & 5,51 & 5,49 & 6,66 & 1,09 \\
\hline & 12 & 16,71 & 5,64 & 1,05 & 1,65 & 8,94 & 11,98 & 7,08 & 10,64 & 35,43 & 0,89 \\
\hline & 18 & 13,08 & 4,51 & 1,48 & 4,44 & 5,47 & 15,12 & 4,48 & 6,68 & 43,43 & 1,31 \\
\hline & 24 & 12,19 & 4,68 & 2,20 & 7,07 & 4,83 & 19,89 & 4,09 & 5,83 & 37,92 & 1,31 \\
\hline & 30 & 13,58 & 5,44 & 2,30 & 7,36 & 5,05 & 19,70 & 3,82 & 5,42 & 35,87 & 1,46 \\
\hline & 36 & 21,11 & 5,11 & 2,05 & 6,29 & 4,59 & 16,87 & 3,37 & 5,01 & 33,43 & 2,18 \\
\hline \multirow{7}{*}{ M } & 1 & 0,00 & 0,00 & 0,11 & 0,15 & 0,00 & 1,99 & 0,00 & 97,75 & 0,00 & 0,00 \\
\hline & 6 & 3,98 & 10,43 & 10,19 & 0,27 & 1,51 & 2,45 & 6,93 & 60,48 & 2,29 & 1,47 \\
\hline & 12 & 5,13 & 7,80 & 17,38 & 0,19 & 2,07 & 2,42 & 7,27 & 49,28 & 6,99 & 1,48 \\
\hline & 18 & 7,74 & 5,34 & 22,79 & 0,36 & 2,09 & 1,64 & 4,98 & 42,15 & 9,12 & 3,79 \\
\hline & 24 & 10,35 & 3,92 & 25,56 & 0,52 & 1,49 & 1,22 & 3,39 & 37,90 & 11,18 & 4,46 \\
\hline & 30 & 10,65 & 3,14 & 26,21 & 0,46 & 1,10 & 1,79 & 2,48 & 35,70 & 14,56 & 3,90 \\
\hline & 36 & 10,55 & 2,78 & 25,76 & 0,37 & 0,98 & 3,13 & 1,97 & 33,66 & 17,56 & 3,25 \\
\hline \multirow{3}{*}{ 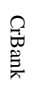 } & 1 & 0,00 & 0,00 & 0,05 & 0,00 & 0,00 & 0,06 & 99,88 & 0,01 & 0,00 & 0,00 \\
\hline & 6 & 5,82 & 3,69 & 7,76 & 0,35 & 1,36 & 1,72 & 68,48 & 8,68 & 0,66 & 1,48 \\
\hline & 12 & 27,70 & 2,45 & 3,99 & 1,61 & 0,87 & 7,86 & 29,35 & 20,71 & 1,57 & 3,88 \\
\hline
\end{tabular}




\begin{tabular}{|c|c|c|c|c|c|c|c|c|c|c|c|}
\hline & 18 & 34,00 & 1,73 & 3,36 & 1,32 & 0,54 & 6,83 & 14,58 & 22,18 & 10,90 & 4,57 \\
\hline & 24 & 28,64 & 1,55 & 5,20 & 1,04 & 0,37 & 5,08 & 10,03 & 22,39 & 21,68 & 4,02 \\
\hline & 30 & 23,38 & 1,88 & 7,37 & 1,37 & 0,29 & 6,35 & 7,70 & 21,34 & 26,97 & 3,34 \\
\hline & 36 & 20,70 & 2,51 & 9,32 & 1,75 & 0,40 & 8,25 & 6,44 & 20,44 & 27,30 & 2,89 \\
\hline \multirow{7}{*}{ E } & 1 & 0,04 & 0,00 & 0,02 & 0,02 & 0,00 & 0,29 & 0,00 & 14,03 & 85,61 & 0,00 \\
\hline & 6 & 4,60 & 12,60 & 0,22 & 1,46 & 1,02 & 2,06 & 4,80 & 6,03 & 51,01 & 16,19 \\
\hline & 12 & 6,51 & 9,94 & 2,03 & 2,25 & 1,08 & 5,87 & 6,85 & 6,23 & 48,57 & 10,66 \\
\hline & 18 & 5,70 & 8,68 & 2,20 & 2,69 & 1,44 & 10,68 & 5,97 & 5,36 & 47,62 & 9,66 \\
\hline & 24 & 6,75 & 8,47 & 2,08 & 3,90 & 1,46 & 13,27 & 5,34 & 4,87 & 44,87 & 9,00 \\
\hline & 30 & 14,01 & 8,40 & 2,63 & 4,47 & 2,07 & 12,34 & 4,72 & 4,28 & 39,12 & 7,95 \\
\hline & 36 & 25,40 & 7,43 & 3,83 & 4,13 & 2,11 & 10,04 & 4,06 & 3,62 & 32,14 & 7,24 \\
\hline \multirow{7}{*}{$\overrightarrow{\tilde{x}}$} & 1 & 18,45 & 0,12 & 0,01 & 1,50 & 0,02 & 0,12 & 0,00 & 0,37 & 0,01 & 79,39 \\
\hline & 6 & 24,63 & 2,15 & 1,79 & 6,12 & 1,44 & 0,21 & 10,58 & 9,74 & 3,36 & 39,98 \\
\hline & 12 & 21,76 & 2,49 & 6,92 & 8,43 & 1,84 & 1,59 & 9,50 & 11,62 & 5,92 & 29,93 \\
\hline & 18 & 22,80 & 2,81 & 7,31 & 6,98 & 2,09 & 6,09 & 8,68 & 9,70 & 7,25 & 26,28 \\
\hline & 24 & 22,87 & 2,68 & 7,27 & 6,56 & 2,18 & 7,69 & 8,49 & 9,08 & 7,63 & 25,55 \\
\hline & 30 & 24,00 & 2,70 & 7,14 & 6,36 & 2,89 & 7,55 & 8,26 & 8,82 & 7,44 & 24,84 \\
\hline & 36 & 30,42 & 2,52 & 6,34 & 5,62 & 2,88 & 7,07 & 7,59 & 8,23 & 6,64 & 22,69 \\
\hline
\end{tabular}

\section{Impulse response dan Variance Decomposition Transmisi Internasional}

Pengaruh kejutan kebijakan moneter melalui suku bunga acuan dalam negeri $(\mathrm{R})$ terhadap transmisi perdagangan internasional melalui aktivitas ekspor dan impor diilustrasikan gambar 8. Hasil estimasi koefisien matriks nilai tukar berpengaruh signifikan terhadap ekspor dan impor. Inovasi positif suku bunga yang diintepretasikan dengan apresiasi rupiah, direspon negatif oleh ekspor dan impor.

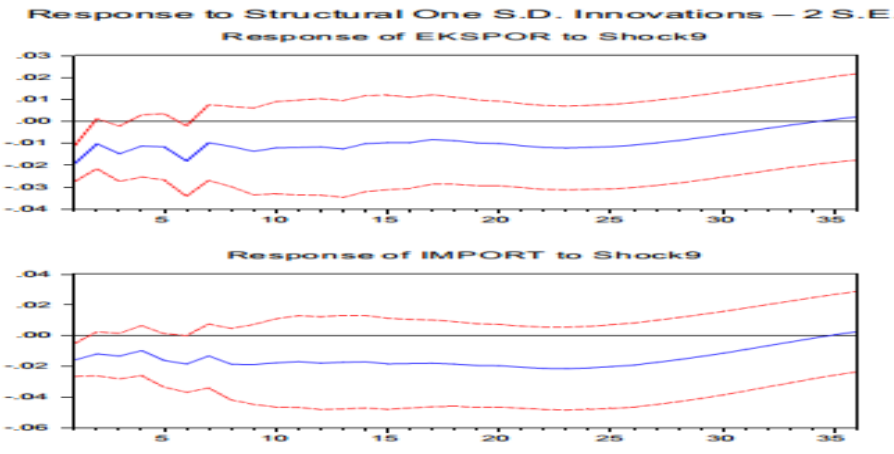

Gambar 8

Impuls response Ekspor dan Impor terhadap kejutan $\mathbf{R}$

Suku bunga melalui nilai tukar berpengaruh signifikan terhadap perdagangan internasional, melalui ekspor dan impor pada bulan pertama. Kedua variabel, ekspor dan import merespon kebijakan moneter dengan pergerakan yang 
relatif sama. Fluktuasi respon berlangsung selama satu semester pertama yang artinya pengaruh kejutan hanya berdampak selama enam bulan pertama. Apresiasi rupiah direspon spontan dan signifikan eskpor dibulan pertama dengan tren kenaikan ekspor sebelum mulai mengalami penurunan pada bulan keduaImpor merespon kejutan R kenaikan impor, siginfikan hanya diawal kejutan tidak pada bulan kedua. Respon ini sesuai dengan terori bahwa apresiasi mata uang domestik mendorong kenaikan impor. Indikasi “ambiguous” kejutan suku bunga bunga terlihat dari respons kedua variabel.

Hasil estimasi Variance Decomposition pada tabel 7, fluktuasi variabel ekspor 30 persen dijelaskan oleh dirinya sendiri, kemudian 20 persen FFR, 15 persen nilai tukar dan 10 persen suku bunga (R). Fluktuasi impor 80 persen dijelaskan dirinya sendiri pada kuartal pertama, kemuan 30 persen FFR dan suku bunga (R).

Tabel 7

Variance Decomposition ekspor dan Impor

\begin{tabular}{|c|c|c|c|c|c|c|c|c|c|c|c|c|c|}
\hline & Month & FFR & WOP & PDB & CPI & JSX & M2 & $\mathrm{CR}$ & RcrB & $\mathrm{R}$ & E & Ekspor & Import \\
\hline \multirow{7}{*}{$\begin{array}{l}\frac{M}{\lambda} \\
\frac{\hat{\hat{n}}}{0} \\
\stackrel{9}{n}\end{array}$} & 1 & 0,00 & 0,00 & 1,28 & 0,18 & 0,00 & 0,07 & 0,00 & 1,36 & 13,03 & 0,00 & 84,07 & 0,00 \\
\hline & 6 & 6,79 & 7,21 & 1,82 & 1,32 & 5,34 & 0,46 & 9,54 & 2,84 & 13,78 & 9,56 & 37,64 & 3,70 \\
\hline & 12 & 24,95 & 4,04 & 1,42 & 1,76 & 3,52 & 0,35 & 6,47 & 1,52 & 10,78 & 5,71 & 25,33 & 14,16 \\
\hline & 18 & 22,02 & 3,52 & 1,47 & 1,71 & 4,33 & 2,22 & 6,30 & 1,32 & 11,88 & 4,94 & 25,27 & 15,04 \\
\hline & 24 & 19,62 & 3,21 & 1,39 & 2,11 & 4,42 & 4,32 & 5,62 & 1,93 & 13,46 & 4,47 & 23,41 & 16,04 \\
\hline & 30 & 18,40 & 2,95 & 1,28 & 2,41 & 4,22 & 5,70 & 4,98 & 3,09 & 13,67 & 4,03 & 22,67 & 16,60 \\
\hline & 36 & 21,97 & 2,82 & 1,61 & 2,71 & 4,65 & 5,50 & 4,50 & 3,41 & 12,30 & 3,69 & 21,58 & 15,26 \\
\hline \multirow{7}{*}{ 冚 } & 1 & 0,00 & 0,00 & 0,07 & 0,17 & 0,00 & 0,03 & 0,00 & 0,57 & 5,48 & 0,00 & 0,00 & 93,67 \\
\hline & 6 & 13,27 & 14,07 & 4,71 & 2,21 & 4,11 & 4,10 & 5,09 & 0,64 & 9,24 & 7,53 & 2,30 & 32,74 \\
\hline & 12 & 36,80 & 6,07 & 2,88 & 2,31 & 3,29 & 2,88 & 6,10 & 1,67 & 8,60 & 4,53 & 5,31 & 19,56 \\
\hline & 18 & 33,37 & 5,32 & 2,45 & 2,32 & 3,45 & 2,97 & 6,59 & 1,53 & 11,71 & 4,12 & 7,55 & 18,63 \\
\hline & 24 & 29,10 & 4,89 & 2,24 & 3,24 & 3,50 & 4,80 & 5,75 & 1,76 & 15,40 & 3,60 & 6,95 & 18,79 \\
\hline & 30 & 25,84 & 4,58 & 2,07 & 3,90 & 3,25 & 7,26 & 5,08 & 2,45 & 16,51 & 3,19 & 7,18 & 18,71 \\
\hline & 36 & 26,45 & 4,54 & 1,93 & 4,38 & 3,62 & 8,07 & 4,68 & 2,75 & 15,48 & 2,98 & 7,51 & 17,59 \\
\hline
\end{tabular}

\section{Impulse response dan Variance Decomposition Perilaku Konsumsi Pribadi dan Investasi Pribadi.}


Gambar 9 tersebut dibawah ini, memperlihatkan response komponen PDB variabel konsumsi (Pcon) dan investasi pribadi (Pinv) terhadap impulse dari kejutan suku bunga domestik (R). Kejutan satu standar deviasi suku bunga $\mathrm{R}$ berdampak positip terhadap konsumsi dan Investasi yang direspon dengan lag satu kuartal, sebelum mulai menurun dan kembali ke titik keseimbangan pada jangka panjang di bulan ke 36. Sesuai dengan teori, dampak inovasi positif suku bunga tidak berpengaruh langsung terhadap konsumsi pribadi (rumah tangga) dan investasi pribadi (kredit modal kerja). Fase delayed respon variabel konsumsi dijelaskan sebagai intertemporal choice. Dampak kejutan suku bunga terhadap konsumsi equivocal. Respon positif dan signifikan variabel konsumsi dan investasi dalam penelitian ini dipengaruhi oleh inovasi positif suku bunga yang didorong oleh income effect. Dapat disimpulkan bahwa perilaku konsumsi pribadi dan investasi pribadi digerakkan oleh faktor lain dan bukan karena stance kebijakan moneter (suku bunga, R).

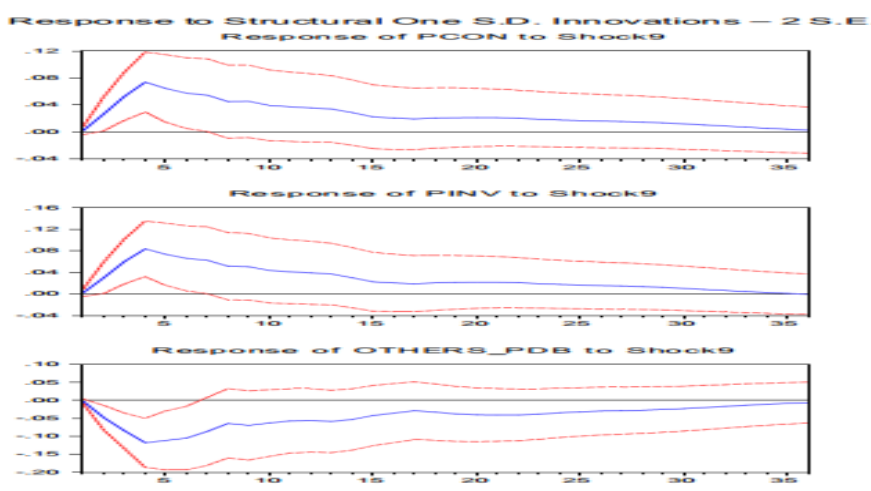

Gambar 9

Impuls respon Pcon dan Pinv terhadap kejutan Suku bunga (R) 
Variance Decomposition konsumsi (Pcon) 60 persen FFR dan 30 persen CPI pada triwulan pertama. Setelahnya, 40 persen dijelaskan oleh CPI, 20 persen FFR, 15 persen RcrBank, 15 persen suku bunga dan variabel lainnya (tabel 8).

Tabel 8

Variance Decomposition Pcon dan Pinv

\begin{tabular}{|c|c|c|c|c|c|c|c|c|c|c|c|}
\hline & Period & Pcon & Pinv & Opdb & CPI & M2 & $\mathrm{CrB}$ & $\mathrm{RCr}$ & JSX & $\mathrm{R}$ & $\mathrm{E}$ \\
\hline \multirow{7}{*}{$\stackrel{\vartheta}{\varrho}$} & 1 & 63,15 & 1,04 & 2,96 & 22,20 & 5,09 & 0,26 & 0,38 & 0,04 & 0,03 & 4,86 \\
\hline & 6 & 29,55 & 5,16 & 6,64 & 29,08 & 1,03 & 0,40 & 8,41 & 0,23 & 18,13 & 1,37 \\
\hline & 12 & 21,07 & 6,15 & 6,20 & 34,65 & 0,79 & 0,49 & 11,70 & 0,27 & 17,71 & 0,97 \\
\hline & 18 & 18,62 & 6,28 & 5,22 & 35,58 & 1,03 & 0,42 & 14,95 & 0,68 & 16,19 & 1,02 \\
\hline & 24 & 18,23 & 5,48 & 5,35 & 36,00 & 1,46 & 0,46 & 15,89 & 1,15 & 14,85 & 1,11 \\
\hline & 30 & 17,92 & 5,05 & 6,39 & 35,99 & 1,92 & 0,48 & 15,70 & 1,26 & 14,14 & 1,15 \\
\hline & 36 & 17,55 & 4,99 & 7,33 & 35,61 & 2,36 & 0,47 & 15,49 & 1,25 & 13,81 & 1,16 \\
\hline \multirow{7}{*}{$\underset{\gtrless}{\Xi}$} & 1 & 59,83 & 6,24 & 2,80 & 21, & 4,82 & 0,25 & 0,36 & 0,04 & 0,03 & 4,61 \\
\hline & 6 & 27,56 & 7,30 & 7,21 & 28,49 & 0,98 & 0,42 & 8,57 & 0,20 & 17,77 & 1,51 \\
\hline & 12 & 19,36 & 7,48 & 6,82 & 34,28 & 0,90 & 0,52 & 11,98 & 0,32 & 17,19 & 1,15 \\
\hline & 18 & 17,08 & 7,59 & 5,81 & 35,08 & 1,25 & 0,47 & 15,31 & 0,63 & 15,54 & 1,25 \\
\hline & 24 & 16,95 & 6,70 & 6,26 & 35,12 & 1,76 & 0,48 & 16,14 & 0,86 & 14,38 & 1,35 \\
\hline & 30 & 16,78 & 6,26 & 7,58 & 34,79 & 2,17 & 0,49 & 15,91 & 0,94 & 13,71 & 1,36 \\
\hline & 36 & 16,48 & 6,22 & 8,62 & 34,34 & 2,48 & 0,48 & 15,71 & 0,95 & 13,39 & 1,35 \\
\hline
\end{tabular}

\section{SIMPULAN DAN SARAN}

\section{Simpulan}

1. Hasil analisa empiris menemukan bahwa dampak kebijakan moneter ketat (contractionary) terhadap variabel-variabel domestik sebagian besar sesuai dengan teori ekonomi dan ekspektasi. Namun, ditemukan price puzzle dan exchange rate puzzle yang mengidindikasikan kebijakan moneter kurang efektif dalam mengendalikan laju inflasi di Indonesia, hal ini ditandai dengan adanya kenaikan harga disaat kontraksi moneter berlangsung. Hal senada juga terjadi pada nilai tukar, kebijakan moneter ketat tidak efektif dalam menjaga stabilitas rupiah, yang dibuktikan dengan terdepresiasinya rupiah disaat kebijakan moneter ketat dijalankan. 
2. Dari hasil estimasi variance decomposition memperlihatkan bahwa saluran kredit bank lebih efektif mempengaruhi tingkat harga daripada output. Demikian juga nilai tukar, lebih besar pengaruhnya terhadap harga daripada output. Suku bunga domestik hanya berdampak dari jangka menengah sampai jangka panjang, dimana pengaruhnya lebih berdampak pada output dibandingkan harga. Terakhir, saluran harga aset merupakan daluran dengan dampak terkecil dalam menjelaskan fluktuasi output maupun harga.

3. Hasil penelitian menemukan bahwa kejutan eksternal (FFR) lebih besar pengaruhnya terhadap fluktuasi ekonomi Indonesia dibandingkan dengan kejutan domestik. Hal ini diperkuat dengan hasil estimasi impuls response dan variance decomposition. FFR mempengaruhi PDB dengan lag, tidak jauh berbeda $\mathrm{R}$ juga mempengaruhi PDB dengan lag, namun estimasi variance decomposition menjelaskan pengaruh FFR lebih besar mencapai 30 persen sedangkan $\mathrm{R}$ hanya berkontribusi tidak lebih dari 10 persen. Kontribusi FFR terhadap tingkat harga (CPI) lebih dominan dengan R dengan masing-masing kontribusi 40 persen dan 5 persen secara berurutan. Hal ini sesuai dengan asumsi bahwa ekonomi kecil terbuka sensitif dan dominan dipengaruhi oleh kejutan dari luar negeri. FFR berkontribusi 20 persen dan R 15 persen dalam menggerakkan fluktuasi Ekspor, sedangkan kontribusi terhadap fluktuasi impor FFR menyumbang sebesar 30 persen dan R 10 persen. Hal ini sesuai dengan asumsi bahwa ekonomi kecil terbuka sensitif dan dominan dipengaruhi oleh kejutan dari luar negeri. 
4. Kejutan suku bunga domestik (R) berhubungan positip terhadap pergerakan konsumsi (Pcon) dan investasi (Pinv), Respon positif dan signifikan variabel konsumsi dan investasi dalam penelitian ini dipengaruhi oleh inovasi positif suku bunga yang didorong oleh income effect.

\section{SARAN}

1. Menggunakan kebijakan moneter untuk mempengaruhi nilai tukar menjadi upaya memperkecil terjadinya exchange rate puzzle atau mencegah frekuensi fluktuasi nilai tukar tinggi. Bank sentral disarankan untuk menggunakan uang beredar sebagai acuan dibanding dengan suku bunga. Selanjutnya hal krusial lainnya yang harus diperhatikan adalah tingginya harga produksi domestik maka faktor structural, institusi dan daktor legal lainnya yang terkait dengan pasar tenaga kerja perlu diperbaiki

2. Saluran transmisi kredit bank menjadi saluran dominan terhadap fluktuasi harga domestik, maka fungsi intermediasi lembaga perbankan perlu di restorasi. Sehingga peran bank sentral untuk mengawasi intermediasi perbankan harus lebih ditingkatkan. Excess likuiditas menjadi salah satu faktor penghambat kegiatan ekonomi.

3. Upaya untuk mengembangkan sistem pasar keuangan dan stabilitas makro finansial perlu ditingkatkan agar saluran transmisi moneter efektif dan tepat waktu dalam mentransmisikan kebijakan moneter ke pasar uang maupun pasar barang. Sehingga pengaruh kejutan eksternal tidak berdampak besar.

4. Dalam mengatasi kecilnya kontribusi kebijakan moneter terhadap konsumsi dan investasi, terbatasnya akses terhadap kredit bank untuk konsumsi dan 
investasi pribadi dapat diatasi dengan mempermudah akses kredit dan mensosialisasikan kemasyarakat tingkat ekonomi menengah.

\section{REFERENSI}

Afandi, A. 2005. Monetary policy transmission mechanism and structural breaks in Indonesia, (Dissertation), New South Wales, University of Wollongong.

Amisano, G. \& Giannini, C.1997. Topics in structural VAR econometrics, Springer, Berlin.

Aslanidi, O. 2007. The optimal monetary policy and the channels of monetary transmission mechanism in CIS-7 countries: The case of Georgia, Discussion Paper Series of Center for Economic Research and Graduate Education, p: 2007-171, Czech Republic, Charles Universtiy,

Bai, J, \& Perron, P. 2003. Computation and analysis of multiple structural change models. Journal of Applied Econonometrics,(18) p: 1-22

Berkelmans, L. 2005. Credit and monetary policy: an Australian SVAR, Reseach Discussion Paper, 2005-06, Reserve Bank of Australia

Bernanke, B. S. \& Mihov, I. 1998. Measuring monetary policy, The Quarterly Journal of Economics, 113(3) p : 869-902.

Blanchard, O. J. \& Quah, D. 1989. The dynamic effects of aggregate demand and supply disturbances, The American Economic Review, 79(4) p : 655-673

Boediono (1994), Problems of Implementing Monetary Policy in Indonesia, in Ross H. McLeod (Ed.), Indonesia Assessment 1994: Finance asa Key Sector in Indonesia's Development, Canberra, Australian National University,

Cecchetti, S. G \& Krause, S. 2001. Financial structure, macroeconomic stability and monetary policy, XII Symposium of Moneda y Credito, Madrid.

Cushman, D. O. \& Zha, T. 1997. Identifying monetary policy in a small open economy under flexible exchange rates, Journal of Monetary Economics, 39(3) p : 33-448

Dungey, M. \& Pagan, A. 2000. A structural VAR model of the Australian economy, Economic Record, 76(235) p : 321-342.

Fleming, J. M 1962. Domestic financial policies under fixed and under floating exchange rates, International Monetary Fund Staff Papers, 9(3) p : 369. 227

Friedman, M. 1957. A theory of the consumption function, Princeton: Princeton University Press.

Gottschalk, J. 2001 . An introduction into the SVAR methodology: identification, interpretation and limitations of SVAR models. Kiel Working Paper, Kiel Institute of World Economics. 1072 p : 42.

Gujarati, D. N. \& Porter, D. C. 2009 . Basic econometrics, McGraw-Hill Irwin, Boston.

Hyndman, Rob. Jan Verbesselt, Glenn Newnham and Darius Culvenor (2010) "Detecting trend and seasonal changes in satellite image time series," Journal of Remote Sensing of Environment,114(1): 106-115 
Kim, S. \& Roubini, N. 2000. Exchange rate anomalies in the industrial countries: a solution with a structural VAR approach, Journal of Monetary Economics, 45(3) p : 561-586

Loayza, N. \& Schmidt-Hebbel, K. 2002. Monetary policy functions and transmission mechanisms: an overview in Monetary Policy: Rules and Transmission Mechanisms, edited, Central Bank of Chile, Santiago, Chile

Lütkepohl, Helmut. \& Jürgen Wolters 2003. Transmission of German Monetary Policy in the Pre-Euro Period, Macroeconomic Dynamics, 7, pp : 711-733

Mankiw, N. G. 2010. Macroeconomics, Worth Publishers, New York

Mishkin, F. S. 1995. Symposium on the monetary transmission mechanism, The Journal of Economic Perspectives, 9(4) p : 3-10.

Modiglina, F. \& Brumberg, R. 1954. Utility Analysis and the Consumption Function, in Post-Keynesian Economics, edited by K. Kurihana, Rutger University Press: 338-436.

Nguyen, H.T. 2014. Monetary transmission mechanism analysis in small, open economy: the case of Vietnam, (dissertation), New South Wales, University of Wollongong.

Sims, C. 1986. Are forecasting models usable for policy analysis?, Federal Reserve Bank of Minneapolis. Quarterly Review - Federal Reserve Bank of Minneapolis, 10(1) $\mathrm{p}: 2$.

Taylor, J. B. 2002. The monetary transmission mechanism and the evaluation of monetary policy rules, in Monetary Policy: Rules and Transmission Mechanisms, edited, Central Bank of Chile, Santiago, Chile

Warjiyo, Perry. 2016. Kebijakan Bank Sentral, Teori dan Praktek. Jakarta: PT Raja Grafindo Persada. 